\title{
Understanding and analysing competency based curriculum in pharmacology for developing syllabus and teaching schedules
}

\author{
Gurudas Khilnani $^{1}$, Ajeet Kumar Khilnani ${ }^{2 *}$, Rekha Thaddanee ${ }^{3}$
}

\begin{abstract}
${ }^{1}$ Department of Pharmacology, ${ }^{2}$ Department of Otorhinolaryngology, ${ }^{3}$ Department of Pediatrics, Gujarat Adani Institute of Medical Sciences and GK General Hospital, Bhuj, Kachchh, Gujarat, India
\end{abstract}

Received: 26 February 2020

Revised: 20 April 2020

Accepted: 22 April 2020

\section{*Correspondence:}

Dr. Ajeet Kumar Khilnani,

Email: ajeetkhilnani@gmail.com

Copyright: $\odot$ the author(s), publisher and licensee Medip Academy. This is an open-access article distributed under the terms of the Creative Commons Attribution Non-Commercial License, which permits unrestricted non-commercial use, distribution, and reproduction in any medium, provided the original work is properly cited.

\begin{abstract}
The competency based curriculum has already been implemented in phase-I ( $1^{\text {st }}$ professional MBBS) and medical institutes, through curriculum committees, are gearing up for designing and developing curricular contents for phase-II training beginning from October, 2020. We have analysed curricular components as given in CBME documents with respect to distribution of contents and time allotted for cognitive and skill training and assessment. The objectives of this analysis are to understand distinctive features, identify elements required for organization of teaching sessions and facilitate preparation of teaching schedules. We segregated competencies according to corresponding system and domain of learning to distribute teaching hours. It was observed that 64 competencies in cognitive domain shall be covered in 80 hours assigned for lectures. The new curriculum has given importance to clinically relevant topics such as drug regulations, pharmaco-economics, pharmacology of eye and skin disorders, vaccines, national health programs (would require integration), environmental pollutants, food adulterants, stings and bites, and pharmacological considerations in geriatric and paediatric therapy. Ironically, antimicrobial agents and anti-fungals do not appear in the document as separate competencies. The 138 non-lecture hours can be divided into small group discussions (seminars) and tutorials for 19 hours each and remaining 100 hours can be reserved for practicals (skill training). About $27 \%$ of time assigned for practical training shall be required for developing proficiency for certification in 4 competencies and 25 competencies in cognitive domain shall require integration. Finally, steps are described to construct subject specific sessions giving one example each for a non-integrated and an integrated session.
\end{abstract}

Keywords: Assessment, Competency, Medical education, Pharmacology, Syllabus, Viva voce

\section{INTRODUCTION}

With the release of GME-19 regulations for phase wise implementation of competency based medical education (CBME), it has been possible for the medical institutions across the country to complete first phase curriculum in the year 2019. ${ }^{1}$ It is imperative to start preparations for implementation of curriculum for second phase well before the students are promoted to IInd professional MBBS in October, 2020. The deans, members of institutional curriculum committee and subcommittee shall play active roles in finalizing time schedules and contents according to the subject wise competencies described in curricula Volumes I-III of Medical Council of India. $^{2-4}$

The purpose of this presentation is to facilitate understanding and analysing competency based pharmacology curriculum (CBPC) so that it becomes easier to develop teaching learning material (TLM) and design teaching schedules for effective implementation. 


\section{METHODS}

After careful perusal of the pharmacology curriculum (competencies, sub-competencies, learning objectives and domains, TLMs and assessment tools) from the modules provided by the Medical Council of India, we analysed curricular contents in terms of-

A: Distribution of teaching hours as lectures and nonlectures and further distributing these hours among Small group discussions (seminars) tutorials, practicals integrated teaching and SDL, acronymed as STUPITS hours.

B: Developing teaching and assessment methods for acquisition of knowledge (K/KH) and skills ( $\mathrm{S} / \mathrm{SH})$ about drugs. The competencies were segregated in system wise sub-competencies and objectives were driven. Thereafter, steps for construction of teaching sessions were finalized, and

$C$ : Exploring scope of integration with subjects in same or different phases. A sample of such teaching session was also developed

\section{RESULTS}

\section{Salient features of pharmacology curriculum}

The features that distinguish CBPC from traditional curriculum are division of clinically oriented competencies (outcomes) into subject based sub-competencies, emphasis on self-directed learning (SDL for 12 hours) for experiential learning, scope of alignment and integration for reducing redundancy and enhancing applicative use of previously acquired training, certification of core skills, formative nature of periodic and internal assessments, and boundaries of theory and practicals of traditional curriculum being overarched by learning domains in knowledge and skills. Thus, practicals form a part of skill domain. For the ease of understanding, term practical is used interchangeably for skill training in this article.

The new curriculum converts the systemic approach used in conventional curriculum into (outcome based) competencies involving all the learning domains with scope for inter-disciplinary integration. Therefore, this requires reconstruction of syllabus for effective implementation in given time. Since, the duration of training in phase-II is reduced to 12 months; there is corresponding reduction in teaching hours (Table 1). If we compare system wise contents of traditional curriculum with sub-competencies of new curriculum, we find that some topics are given less and others more emphasis, and some newer ones are added.

\section{Coverage}

A comparison between GME-1997 and GME-2019 is shown in Table 1 . The duration of II $^{\text {nd }}$ professional MBBS in new curriculum is reduced to 12 months and the last month is assigned for assessments. Thus, there shall be 11 months for effective teaching. There are 230 hours for pharmacology curriculum divisible into 80 lecture hours (theory classes) and 150 non-lecture hours (others). The components of others (Acronym-STuPITS) include small group discussions (SGDs), tutorials, practicals, integrated (vertical and horizontal) teaching and self directed learning (12 hours).

Table 1: Comparative training hours and assessment in Pharmacology in GME-1997 and GME-2019.

\begin{tabular}{|lll|}
\hline $\begin{array}{l}\text { Parameter } \\
\text { Semesters } \\
\text { (months) }\end{array}$ & $3(18)$ & $\begin{array}{l}\text { GME 2019 } \\
\text { examinations }\end{array}$ \\
\hline Total hours & 300 in 18 months & 230 in 12 months \\
\hline $\begin{array}{l}\text { Deductive } \\
\text { lectures } \\
\text { (hours) }\end{array}$ & 100 & 80 \\
\hline $\begin{array}{l}\text { Non } \\
\text { deductive }\end{array}$ & $\begin{array}{l}\text { Practicals and } \\
\text { tutorials (200) }\end{array}$ & STuPITS (138 hours) \\
\hline Marks & 150 & SDL (12 hours) \\
\hline $\begin{array}{l}\text { Internal } \\
\text { assessment } \\
\text { marks }\end{array}$ & $\begin{array}{l}\text { to university } \\
\text { marks } \\
\text { (35\% aggregate } \\
\text { as eligibility } \\
\text { criteria) }\end{array}$ & $\begin{array}{l}\text { No contribution to } \\
\text { angregrite } \\
\text { and separate pass } \\
\text { criteria) }\end{array}$ \\
\hline Viva marks & $\begin{array}{l}\text { 15 (contribute to } \\
\text { theory Marks) }\end{array}$ & $\begin{array}{l}\text { Contribute to practicals } \\
\text { (marks not specified) }\end{array}$ \\
\hline
\end{tabular}

\section{Assigning teaching hours}

The pharmacology curriculum is divisible into 5 topics consisting of 85 outcomes (64 in domain of knowledge, 14 in skills and 7 in communication). Of 64 competencies, only 4 are certifiable. Furthermore, knowledge component of teaching (conventional theory) can be clubbed in 25 broad subject heads which can be covered as lectures, requiring 118 hours as lectures. Since total 80 hours are assigned we shall require covering the knowledge subcompetencies in non-lecture teaching consisting of SGD, tutorials, SDL and integrated sessions. This is because some competencies require more than one hour lecture. These include anti-hypertensives, drugs for peptic ulcer, malaria and tuberculosis. The details of breakup of 138 hours for small group learning as tutorials or seminars or Integrated learning are not provided in GME-2019. Perhaps, it is left for institutional curriculum subcommittees to devise breakup according to the subject needs. A suggestive breakup is shown in Table 2. The skill training and certification would require only 100 hours out of 138 hours (Table 3 ), thus, remaining 38 (138-100) hours can be equally divided for SGDs and tutorials (Figure 1). We believe tutorials are important for reinforcement of teaching and periodic assessments. Any of 3 types of TLMs (lecture, SGD, and tutorial) can be integrated wherever required. 
Table 2: Detailed breakup of competencies in knowledge domain.

\begin{tabular}{|c|c|c|c|c|c|c|}
\hline \multirow{3}{*}{ System or section } & \multirow{3}{*}{ PH codes } & \multirow{3}{*}{$\begin{array}{l}\text { Total } \\
\text { PH codes }\end{array}$} & \multicolumn{4}{|c|}{ Total hours needed } \\
\hline & & & \multirow{2}{*}{ Lectures } & \multicolumn{3}{|c|}{ Non lecture } \\
\hline & & & & Tutorials & SGD & SDL \\
\hline General pharmacology & $\begin{array}{l}\text { PH 1.1-1.12, PH } \\
1.59-1.61, \\
1.63,1.64\end{array}$ & 17 & 16 & 2 & 2 & - \\
\hline Central nervous system & PH 1.18-1.23 & 6 & 10 & 3 & 2 & \multirow{2}{*}{1} \\
\hline Autacoids & PH 1.16 & 1 & 4 & 2 & - & \\
\hline Autonomic nervous system & PH 1.13-1.14 & 2 & 2 & 2 & 2 & 1 \\
\hline Peripheral nervous system & PH $1.15,1.17$ & 2 & 2 & 1 & - & - \\
\hline Renal & PH 1.24 & 1 & 1 & - & 1 & 1 \\
\hline Blood & PH $1.25,1.31,1.35$ & 3 & 5 & 1 & 1 & 1 \\
\hline Cardiovascular & PH $1.26-1.30$ & 5 & 7 & 2 & 1 & 1 \\
\hline Respiratory & PH $1.32-1.33$ & 2 & 2 & - & 1 & 1 \\
\hline Gastrointestinal & PH 1.34 & 1 & 3 & 1 & 2 & 1 \\
\hline Endocrinology & PH 1.36-1.41 & 6 & 6 & 2 & 2 & 2 \\
\hline Chemotherapy general & PH 1.42-1.43 & 2 & 2 & - & 1 & 1 \\
\hline Specific chemotherapy & PH 1.44-1.48 & 5 & 7 & 1 & 2 & 1 \\
\hline Vaccines & PH 1.54 & 1 & 1 & & - & \\
\hline Antiseptics and disinfectants & PH 1.62 & 1 & 1 & & - & \\
\hline Chemotherapy of cancer & PH 1.49 & 1 & 1 & & 1 & \\
\hline \multicolumn{7}{|l|}{ Miscellaneous } \\
\hline $\begin{array}{l}\text { Immuno-modulators and } \\
\text { suppressants }\end{array}$ & PH 1.50 & 1 & 1 & 1 & - & \\
\hline Environmental pharmacology & PH 1.51 & 1 & 2 & & - & 1 \\
\hline Stings and bites & PH 1.52 & 1 & 1 & & & \\
\hline Chelating agents & PH 1.53 & 1 & 1 & - & - & \\
\hline $\begin{array}{l}\text { NHP (communicable and non- } \\
\text { communicable diseases) }\end{array}$ & PH 1.55 & 1 & 2 & & - & \\
\hline $\begin{array}{l}\text { Geriatric and paediatric } \\
\text { pharmacology }\end{array}$ & PH 1.56 & 1 & 1 & - & 1 & \\
\hline Skin & PH 1.57 & 1 & 1 & 1 & - & \\
\hline Ocular pharmacology & PH 1.58 & 1 & 1 & - & - & \\
\hline Total & PH 1.1-1.64 & 64 & 80 & 19 & 19 & 12 \\
\hline
\end{tabular}

Table 3: Detailed breakup of competency hours in practicals.

\begin{tabular}{|c|c|c|c|c|}
\hline Topic (domain) & $\begin{array}{l}\text { Competency } \\
\text { (N) }\end{array}$ & Type & $\begin{array}{l}\text { Required number of } \\
\text { practical sessions } \\
\text { (each of } 2 \text { hours) }\end{array}$ & Total number of hours \\
\hline \multirow{4}{*}{$\begin{array}{l}\text { Knowledge } \\
\text { (SH) }\end{array}$} & PH 1.3 & $\begin{array}{l}\text { Drug formulation and } \\
\text { delivery systems }\end{array}$ & 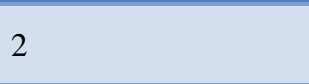 & 4+1 (SGD) \\
\hline & PH 1.9 & Generic/ Brand Names & 1 & 2 \\
\hline & PH 1.10 & Correct prescription & 2 & 4 \\
\hline & PH 1.12 & $\begin{array}{l}\text { Dose calculation in child, } \\
\text { adult, elderly }\end{array}$ & 2 & 4 \\
\hline Total & 4 & & $\mathrm{~L}+\mathrm{P}$ & 15 \\
\hline \multirow{4}{*}{$\begin{array}{l}\text { Skills } \\
\text { clinical } \\
\text { pharmacy }\end{array}$} & PH 2.1 & $\begin{array}{l}\text { Demonstrate use of dosage } \\
\text { forms }\end{array}$ & 2 & 4 \\
\hline & PH 2.2 & ORS & 1 & $2+1$ (revision) $)^{* *}$ \\
\hline & PH 2.3 & IV set-up & 1 & 2 \\
\hline & PH 2.4 & Dose calculation in diseases & 1 & 2 \\
\hline Total & 4 & & DOAPs & 11 \\
\hline
\end{tabular}




\begin{tabular}{|c|c|c|c|c|}
\hline Topic (domain) & $\begin{array}{l}\text { Competency } \\
\text { (N) }\end{array}$ & Type & $\begin{array}{l}\text { Required number of } \\
\text { practical sessions } \\
\text { (each of } 2 \text { hours) }\end{array}$ & Total number of hours \\
\hline \multirow{8}{*}{$\begin{array}{l}\text { Skills } \\
\text { clinical } \\
\text { pharmacology* }\end{array}$} & PH $3.1 *$ & $\begin{array}{l}\text { Write and communicate } \\
\text { generic prescription }\end{array}$ & Skill station 1 & $\begin{array}{l}2+(3 \text { hours for certification }) \\
5 \text { times }=17 \text { hours }\end{array}$ \\
\hline & PH $3.2 *$ & Prescription audit & Skill lab 1 & $\begin{array}{l}2+(2 \text { hours for certification }) \\
3 \text { times }=8 \text { hours }\end{array}$ \\
\hline & PH $3.3 *$ & $\begin{array}{l}\text { Evaluation of drug promo } \\
\text { literature }\end{array}$ & Skill lab 1 & $\begin{array}{l}2+(2 \text { hours for certification }) \\
3 \text { times }=8 \text { hours }\end{array}$ \\
\hline & PH 3.4 & ADR reporting & Skill station 1 & 2 \\
\hline & PH $3.5^{*}$ & P-Drug & Practical 1 & $\begin{array}{l}2+(2 \text { hours for certification }) \\
3 \text { times }=8 \text { hours }\end{array}$ \\
\hline & PH 3.6 & $\begin{array}{l}\text { Interaction with medical } \\
\text { representative }\end{array}$ & Skill station 1 & 2 hours \\
\hline & PH 3.7 & Essential medicine list & Skill station 1 & 3 hours \\
\hline & PH 3.8 & $\begin{array}{l}\text { Communicate with patient } \\
\text { proper use of prescribed } \\
\text { drugs }\end{array}$ & Skill lab 1 & 2 hours \\
\hline Total & 8 & & Skill lab/station & 50 \\
\hline \multirow{2}{*}{$\begin{array}{l}\text { Experimental } \\
\text { pharmacology }\end{array}$} & PH 4.1 & $\begin{array}{l}\text { Drug administration by } \\
\text { routes in mannequins }\end{array}$ & DOAP 2 & 4 \\
\hline & PH 4.2 & Drugs on BP (CAL) & Skill lab 2 & 4 \\
\hline Total & 2 & & & 8 \\
\hline \multirow{8}{*}{ Communication } & & & SGD/ skill station & \\
\hline & PH 5.1 & $\begin{array}{l}\text { Communicate (empathy and } \\
\text { Ethics) on drug use }\end{array}$ & 1 & 2 \\
\hline & PH 5.2 & $\begin{array}{l}\text { Optimal use of drug, device, } \\
\text { storage of drug }\end{array}$ & 2 & 4 \\
\hline & PH 5.3 & $\begin{array}{l}\text { Motivation for adherence to } \\
\text { therapy }\end{array}$ & 1 & 2 \\
\hline & PH 5.4 & Explain cost and compliance & 1 & 2 \\
\hline & PH 5.5 & $\begin{array}{l}\text { Demonstrate caution in } \\
\text { prescribing addictive drugs }\end{array}$ & 1 & 2 \\
\hline & PH 5.6 & $\begin{array}{l}\text { Education to patient and } \\
\text { public about proper use of } \\
\text { PTC and dependence drugs }\end{array}$ & 1 & 2 \\
\hline & PH 5.7 & $\begin{array}{l}\text { Legal and ethical aspects of } \\
\text { drug prescribing }\end{array}$ & 1 & 2 \\
\hline Total & 7 & & & 16 \\
\hline Grand total & 25 & & & 100 \\
\hline
\end{tabular}

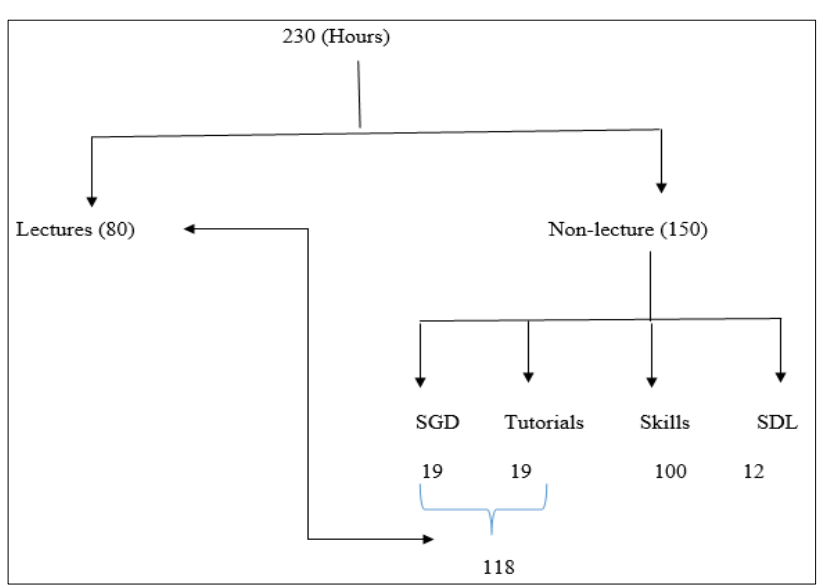

Figure 1: Suggested breakup of teaching hours.

\section{Skill (practical) sessions}

Each skill session can be of 2 hours as in traditional curriculum. Among several skills to be acquired, four procedures shall require certification, i.e., sufficient practice is needed for achieving proficiency as per Miller's pyramid. This can be done in 41 out of 100 assigned hours (Table 3).

\section{Steps in construction of teaching sessions}

Each teaching session can be subject specific stand alone or integrated session. Two examples are given below:

Example 1: $\mathrm{PH}$ 3.5: To prepare and explain a list of $\mathrm{P}$ drugs for a given case/condition. 
This is a core competency, requiring certification, in the domain of Knowledge (K) and Skill (S) and should be achieved at Performance $(\mathrm{P})$ level. Following steps can be used. Time needed is 2.5 hours. It would require integration with internal medicine (IM).

Deriving objectives: An example is given below

Objectives: The learner should be able to explain P-drug concept (1 hour), enumerate steps in identifying a suitable P-drug for a given condition, prepare a list of P-drugs for a given condition, and explain basis of inclusion of each drug in the list and write (perform) independently P-drug for acute migraine, vomiting due to gastritis or colicky abdominal pain (1.5 hours).

\section{Developing TLM}

A Lecture followed by a skill session is suitable. Vertical integration is needed with internal medicine.

\section{Developing method of assessment}

By Logbook and an OSPE session with a check list for assigning marks.

Example 2: Aligned and integrated teaching session (Integration with Forensic medicine, internal medicine, pathology and psychiatry).

PH 1.20: Describe the effects of acute and chronic ethanol intake.

PH 1.21: Describe the symptoms and management of methanol and ethanol poisonings.
Domain: Knowledge

Level: $\mathrm{K} / \mathrm{KH}$

Core: YES

Duration: 2 hours

\section{Deriving sub-competencies and objectives}

These two competencies can be taught together as interdisciplinary aligned and integrated topic (AITo).

The alignment is done with competencies FM 9.4 and Pathology (PA 25.4).

FM 9.4: Describe General Principles and basic methodologies in treatment of poisoning: decontamination, supportive therapy, antidote therapy, procedures of enhanced elimination with regard to Ethanol, methanol, ethylene glycol.

$P A$ 25.4: Describe the pathophysiology, pathology and progression of alcoholic liver disease including cirrhosis (integrates with IM 5.5 \& IM 8.16)

Vertical integration is done with competencies of general medicine (IM 5.5 \& IM 8.16) and Psychiatry (PS 4.4 \& PS 4.6).

PS 4.4: Describe the treatment of alcohol and substance abuse disorders including behavioural and pharmacologic therapy.

PS4.4.1: Describe pharmacotherapy of alcohol abuse.

Table 4: PH 1.20/1.21 Learning objectives of AITo on ethanol in pharmacology.

\begin{tabular}{|c|c|c|c|c|c|c|}
\hline \multirow[b]{2}{*}{ Code } & \multirow[b]{2}{*}{ SLO } & \multirow[b]{2}{*}{ TLM } & \multicolumn{3}{|c|}{ Alignment \& Integration } & \multirow[b]{2}{*}{ Assessment } \\
\hline & & & Alignment & $\begin{array}{l}\text { Vertical/ } \\
\text { horizontal* }\end{array}$ & Linker & \\
\hline $\begin{array}{l}\text { PH } \\
1.20 .1\end{array}$ & $\begin{array}{l}\text { Describe effects of acute ethanol } \\
\text { ingestion }\end{array}$ & $\begin{array}{l}\text { L/ } \\
\text { SGD }\end{array}$ & - & - & - & SAQ \\
\hline $\begin{array}{l}\text { PH } \\
1.20 .2\end{array}$ & $\begin{array}{l}\text { Describe effects of chronic } \\
\text { ethanol ingestion }\end{array}$ & & & $\begin{array}{l}\text { IM } 5.5 \\
\text { PS } 4.4\end{array}$ & - & SAQ \\
\hline $\begin{array}{l}\text { PH } \\
1.21 .1\end{array}$ & $\begin{array}{l}\text { Describe symptoms and } \\
\text { pharmacotherapy in management } \\
\text { of acute ethanol and intake }\end{array}$ & & $\begin{array}{l}\text { FM } 8.8 \\
\text { FM9.4 }\end{array}$ & PS 4.6 & & SAQ/ Viva \\
\hline $\begin{array}{l}\text { PH } \\
1.21 .2\end{array}$ & $\begin{array}{l}\text { Describe symptoms and } \\
\text { pharmacotherapy in management } \\
\text { of acute methanol and ethylene } \\
\text { glycol intake }\end{array}$ & & FM 9.4 & & & SAQ \\
\hline $\begin{array}{l}\text { PH } \\
1.21 .3\end{array}$ & $\begin{array}{l}\text { Describe pharmacotherapy of } \\
\text { Chronic alcoholism }\end{array}$ & - & PA 25.4 & $\begin{array}{l}\text { IM } 5.5 \\
\text { PS } 4.4 \& \\
4.6\end{array}$ & $\begin{array}{l}\text { A case of } \\
\text { Chronic } \\
\text { alcoholism with } \\
\text { poly-neuropathy } \\
\text { and psychosis }\end{array}$ & SAQ/ Viva \\
\hline $\begin{array}{l}\text { PH } \\
1.21 .4\end{array}$ & $\begin{array}{l}\text { Prescribe drug treatment of } \\
\text { alcohol dependence }\end{array}$ & - & - & PS 4.6 & - & Skill station \\
\hline
\end{tabular}

*Abbreviations used from Reference 2. 
Table 5: Suggested 6 days IA schedule.

\begin{tabular}{|llllll|}
\hline Theory 2 hrs & & Practicals (skill assessment) & hours/day & \\
\hline Day & & Day & Batch-A & Batch-B & Batch-C \\
\hline Day 1 & Pharmacology (PH) & Day-4 & MI & PA & PH \\
\hline Day 2 & Pathology (PA) & Day-5 & PA & PH & MI \\
\hline Day 3 & Microbiology (MI) & Day-6 & PH & MI & PA \\
\hline
\end{tabular}

PS 4.6: Enumerate and describe the pharmacologic basis and side effects of drugs used in alcohol and substance abuse.

PS 4.6.1: Describe adverse effects of drugs used in alcohol abuse.

IM 5.5: Describe and discuss the pathophysiology and clinical evolution of alcoholic liver disease.

\section{Developing TLM and assessment methods}

Table 4 describes TLM, integration, and assessment. A correlation can be made by adding a linker - A case with chronic alcoholism with malnutrition and polyneuritis.

\section{Developing assessment plan}

The formative assessment is in-built in all competencies. There shall be 2 internal assessments (IA) during 11 months and one preliminary examination, followed by University examinations in the twelfth month. First IA can be held in the $4^{\text {th }}$ month (January 2021) and second in $8^{\text {th }}$ month (May 2021). The preliminary examination shall be taken in the first week of September 2021. A suggested plan for each IA is shown in Table 5. In addition to above there shall be two IAs each in general medicine (IM), general surgery (SU), obstetrics and gynaecology (OG), Community medicine (CM) and Forensic medicine and toxicology (FM) during phase-2 training. The IA for these five subjects can be planned separately at the end of $6^{\text {th }}$ and $11^{\text {th }}$ month.

\section{DISCUSSION}

A distinct feature of CBPC is emphasis on several aspects which have been ignored in the past. The examples are: including drug regulations and drug acts, nutraceuticals and pharmaco-economics as separate competencies. Lipid lowering agents, antibiotics stewardship program and rationale use of antibiotics, environmental pollutants, food adulterants, stings and bites and ocular pharmacology are shown as separate competencies. However, non-steroidal anti-inflammatory (NSAIDs) and anti-rheumatic drugs have not been identified as separate competencies. Adequate training/learning is required for safe use of NSAIDs. The drugs for shock appear along with antihypertensives as a single competency. The plasma expanders appear with coagulants and anti-coagulants as single competency. It will require organization of intradisciplinary aligned/integrated sessions. Similarly, sex hormones appear with anterior pituitary hormones as single competency whereas, contraceptives appear as a separate competency. It will also require intra-disciplinary integration/ alignment. Antimicrobials and anti-fungals do not appear in the document as separate competencies. Prescribing antimicrobials without adequate knowledge of pharmacology may promote irrational use in future. The antimicrobials can be incorporated in competency on general principles of chemotherapy during preparation of TL sessions. This should also include a session on antimicrobial resistance, aligned with microbiology. Among skill competencies, four are certifiable. We feel that ORS (PH 2.2) and optimal use of medicines and devices (PH 5.12) should also be taught as certifiable competency. National health programs as related to pharmacology can be taught as integrated session with community medicine

The CBME curriculum is analysed to identify elements required for construction of syllabus and teaching hours. Two examples are described to help construction of structured formats for preparing detailed teaching schedule within the limitations of time period of 12 months. We feel that a lot of collaborative effort is required in construction of such formats. Time is propitious to begin the work, share the experiences and overcome the hurdles. It is hoped that using such constructs it will be easier to prepare teaching material for effective learning and assessment. Earlier, we reported the impact of changed recommendations in viva and internal assessment. ${ }^{5}$ Furthermore, Badyal and Sharma (2020) have devised methods and logistics for internal assessment in general which can be integrated during development of pharmacology syllabus. ${ }^{6}$

\section{CONCLUSION}

Understanding and analysing CBPC shall assist institutional curricular subcommittees to assign teaching hours, prepare weekly schedules for lectures, SGDs, and skill sessions, and build time tables for formative assessments throughout the study period.

Funding: No funding sources

Conflict of interest: None declared

Ethical approval: The study was approved by the Institutional Ethics Committee

\section{REFERENCES}

1. Available at: https://mciindia.org/ActivitiWebClient/open/getDocument?path=/Documents/Public/Portal/ 
Gazette/GME-06.11.2019.pdf. Accessed 02 January 2020.

2. Available at: https://www.mciindia.org/CMS/wpcontent/uploads/2020/01/UG-Curriculum-Vol-I.pdf. Retrieved on 15.05.2020.

3. Available at: https://www.mciindia.org/CMS/wpcontent/uploads/2020/01/UG-Curriculum-Vol-II.pdf. Retrieved on 15.05.2020.

4. Available at: https://www.mciindia.org/CMS/wpcontent/uploads/2020/01/UG-Curriculum-VolIII.pdf. Retrieved on 15.05.2020.

5. Khilnani G, Khilnani AK, Thaddanee R. Competency based assessment in pharmacology: implications of changed recommendations in viva voce and internal assessment. Int $\mathbf{J}$ Basic Clin Pharmacol. 2020;9(4):683-9.

6. Badyal DK, Sharma M. Internal assessment in new MBBS curriculum: Methods and logistics. Int J Applied Basic Med Res. 2020;10(2):68-75.

Cite this article as: Khilnani G, Khilnani AK, Thaddanee R. Understanding and analysing competency based curriculum in pharmacology for developing syllabus and teaching schedules. Int $\mathbf{J}$ Basic Clin Pharmacol 2020;9:995-1001. 